\title{
The Effect of Sport on Life Skills in High School Students
}

\author{
Serkan DÜZ ${ }^{1}$ \\ Tahir Volkan ASLAN ${ }^{2}$ \\ Inonu University, Faculty of Sports Science, Malatya, Turkey. \\ Email:serkan.du:@inonu.edu.trTel:+904223410613 \\ ${ }^{2}$ Mersin University, Erdemli Vocational School Department of Travel, Tourism and Entertainment Services, Mersin, \\ Turkey. \\ Email:tahirvolkanaslan@gmail.com Tel:+905065853474
}

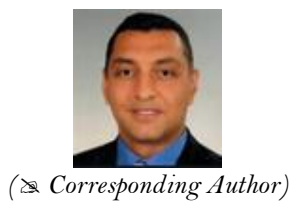

\begin{abstract}
Sport has many psychological and social benefits beyond developing physical skills. It can be used to teach young people important life skills such as teamwork, goal setting, problem solving, decision making, leadership, time management, cognitive, emotional, communication and social skills. Therefore, the aim of this study was to investigate the effect of sports on life skills in high school students. The sample of the study consists of 500 high schools students. Turkish version of the Life Skills Scale for Sports (LSSS) developed by Açak and Düz (2018) was used to data collection. The Mann Whitney U and Kruskal Wallis H tests were used for single and multiple comparisons. The level of significance was accepted as $\mathrm{p}<.05 .61 \%$ of the sample was boys and $39 \%$ of them was girls. There was significant mean score differences in the subscales of emotional and social skills according to gender variable; in the subscales of leadership and goal-setting according to age variable; in the subscales of leadership, goal setting, emotional and social skills according to type of school variable; in the subscales of time management, leadership, teamwork and goal setting according to club license variable; in the subscales of time management and goalsetting according to the sport-year variable; in the subscales of time management, leadership, emotional skills and goal setting according to the number of training variable. As a conclusion, it was observed that life skills improved through sport in high school students.
\end{abstract}

Keywords: Life skills, Sports, Skill development, Secondary education, Social skills, Personal development.

Citation | Serkan DÜZ; Tahir Volkan ASLAN (2020). The Effect of Sport on Life Skills in High School Students. Asian Journal of Education and Training, 6(2): 161-168.

History:

Received: 11 December 2019

Revised: 21 January 2020

Accepted: 25 February 2020

Published: 23 March 2020

Licensed: This work is licensed under a Creative Commons Attribution 3.0 License (oc)

Publisher: Asian Online Journal Publishing Group
Acknowledgement: Both authors contributed to the conception and design of the study.

Funding: This study received no specific financial support

Competing Interests: The authors declare that they have no conflict of interests.

Transparency: The authors confirm that the manuscript is an honest, Transparency: The authors confirm that the manuscript is an honest,
accurate, and transparent account of the study was reported; that no vital features of the study have been omitted; and that any discrepancies from the study as planned have been explained.

Ethical: This study follows all ethical practices during writing.

\section{Contents}

1. Introduction

References 


\section{Contribution of this paper to the literature}

This study contributes to the existing literature by examining the effect of sport on life skills in high school students.

\section{Introduction}

Sport is defined as regular physical activities for different purposes and it is a concept, which is aimed at satisfying the subconscious emotions of human beings, such as integrating set of physical, psychological and mental efforts, and socializing (Eime et al., 2013; Aydemir, 2014). Nowadays, sport is gradually increasing its effect on human life and it is becoming even more important in the society. People now do sports for their personal development as well as their physical and mental abilities. Because there is a strong effect of sport on socializing and strengthening the social ties between individuals in the society. Moreover, it is the most effective form of activity that enables people to prepare for life psychologically and with this aspect contributes to the psychosocial and personal balance (Ghildiyal, 2015).

Skill is expressed as physical, cognitive and behavioral competencies that we need in every field of life and it can be learned, developed and corrected as individually or group (Cronin. and Allen, 2015). Life skills discussed as in the literature are also necessary to cope with the demands and difficulties of daily life (Hodge and Danish, 1999) and "enable individuals to be successful in different environments in which they live such as school, home or neighborhood" (Danish et al., 2004). It is also expressed as the necessary competencies for individuals to maintain their existence effectively in the process of change and development (Kolburan and Tosun, 2011).

In every society, schools play a proactive role in the development of life skills. Because, life skills enable young people to manage their lives successfully and adapt to different life conditions. Acquisition of life skills in school age can be gathered under many factors such as, ethical behavior, fun, learning to learn, goal setting, self-recognition and self-help, emotion management, career planning, responsibility, accurate perception of time and space, participation, collaboration and teamwork, leadership and respect for differences (Gazda and Brooks Jr, 1985; WHO, 1997; Goldsmith, 2000). Therefore, it is an inevitable necessity for young people to have different types of life skills in order to be able to adapt and succeed in the competitive and constantly changing life conditions.

In the last decade, life skills learning through sports has drawn much attention (Gould and Carson, 2008; Holt et al., 2017) and the studies have established links between life skills learning and participation in sports such as leadership, goal setting, communication, and emotional control (Jones and Lavallee, 2009; Johnston et al., 2013). At the same time, it was seen crucial contributions of sportive activities that improved the personality, enhanced the physical and mental health, and developed positive behaviors of the individual (Caterino and Polak, 1999; Kohl and Cook, 2013; Nagaraju, 2016). There had been evidences that most of the skills needed to succeed in sports such as problem solving, time management, goal setting, coping with success and failure, and performing under pressure could be transferred to other living environments (Catalano et al., 2004; Danish et al., 2004).

As the role of social representatives in the transfer of life skills is examined, most studies in the sports psychology literature have focused on coaches and which strategies they use to encourage this transfer (Gould et al., 2007; Camiré and Kendellen, 2016; Whitley et al., 2016). It was also known that the interactions of young people with the key social role models such as coaches, parents and peers in the sport played an important role in life skills learning (Gould and Carson, 2008; Holt et al., 2017). At this point, perspective of parents and the attitude of the teachers who spend the most time with the students, who know them, who know their needs and who are responsible for developing their life skills is also very important.

Social skills, which are defined as the adapting to the social environment and dealing with conflicts that may occur by using appropriate communication ways (Matson et al., 2007) have a major impact on the healthy interpersonal communication, school and family life of individuals (Hejazi et al., 2017). Moreover, social skills which include behaviors of a child towards other children, such as being able to establish good relationships, respect for the rights and feelings of others, and taking into consideration group norms for convenient social behavior (Cetin et al., 2003) are indicated as a stress protective factor for prevention of drop-out and other problematic behaviors (Korkut, 2004).

The way to reach qualitative manpower is to be healthy. Physical education and sports make human will strong, and also play an active role in self-confidence and character formation. Moreover, it facilitates group work and helps people to develop solidarity (Kumar, 2017). During secondary education, in the period when the search for belonging to a social group and finding identity were intense, guiding these needs of the youth in a beneficial and healthy way via physical education and sports will contribute to the process of creating a healthy society and raising generations be attached to national values (Inal, 2003). Basic subjects of life skills comprise the belief of the individual in his/her self-abilities and socialization skills in the society that can demonstrate positive reflections. The acquiring life skills during childhood and youth through sports make this issue even more important because it will prepare them for adulthood.

Therefore, the aim of the study was to investigate the effect of sports on the life skills of high school students in terms of various variables.

\section{Method}

In this part of the study, information about the participants and the analysis of the data are presented.

\subsection{Research Model}

Simple random sampling model was used in sample selection. Random sampling is a part of the sampling technique in which each sample has an equal probability of being chosen.

\subsection{Population}

The population of study was formed by approximately 53621 students studying at four different high schools from each district of Mersin in the 2018-2019 academic year. 


\subsection{Sample}

The formula $\mathrm{Nt}^{2} \mathrm{pq} / \mathrm{d}^{2}(\mathrm{~N}-1)+\mathrm{t}^{2} \mathrm{pq}$ (Sümbüloğlu and Sümbüloğlu, 2009) was used to determine the sample size that will represent the population. With a $95 \%$ confidence interval and $5 \%$ sampling error, the sample size of the study was calculated to be at least 383 students, and accordingly, a questionnaire was applied to a group of 550 high school students. Since 26 of the collected questionnaires contain incomplete and 14 of them include conflicting information, they were excluded from the study. As a result, the total of 500 students was included in the study and formed the sample. The characteristics of the participants are given in Table 1.

\begin{tabular}{|c|c|c|c|}
\hline Variables & Parameters & $\mathbf{N}$ & $\%$ \\
\hline \multirow{5}{*}{ Age } & 15 & 111 & 22.2 \\
\hline & 16 & 190 & 38 \\
\hline & 17 & 129 & 25.8 \\
\hline & 18 & 70 & 14 \\
\hline & Total & 500 & 100 \\
\hline \multirow{2}{*}{ Gender } & Male & 305 & 61 \\
\hline & Female & 195 & 39 \\
\hline \multirow{4}{*}{ School Type } & Anatolian High School & 134 & 26.8 \\
\hline & Business High School & 131 & 26.2 \\
\hline & Sports High School & 171 & 34.2 \\
\hline & Science High School & 64 & 12.8 \\
\hline \multirow{4}{*}{ Sports Year } & O-2 & 160 & 32.0 \\
\hline & $3-5$ & 185 & 37.0 \\
\hline & $6-7$ & 81 & 16.2 \\
\hline & $\geq 8$ & 74 & 14.8 \\
\hline \multirow{4}{*}{ Number of Weekly Training } & 2 & 73 & 14.6 \\
\hline & 3 & 209 & 41.8 \\
\hline & 4 & 108 & 21.6 \\
\hline & $\geq 5$ & 110 & 22.0 \\
\hline \multirow{2}{*}{ Sports Branch } & Individual Sports & 153 & 30.6 \\
\hline & Team Sports & 347 & 69.4 \\
\hline \multirow{2}{*}{ Club License } & Yes & 233 & 46.6 \\
\hline & $\mathrm{No}$ & 267 & 53.4 \\
\hline
\end{tabular}

When Table 1 was examined, it was seen that $61 \%$ of the participants were male and $39 \%$ were female and their ages ranged between 15 and 18. $22.2 \%$ of the participants were 15 years old, $38 \%$ were 16 years old, $25.8 \%$ were 17 years old and 14\% were 18 years old and 134 of them studied at Anatolian high school, 131 were vocational high school, 171 were sports high school and 64 of them are science high school students. While $46 \%$ of the participants have a club license, $93.8 \%$ of them continue their sports activities in the school team.

\subsection{Data Collection Tool}

Ethics committee approval was obtained from the local university after the necessary permissions were obtained from the provincial directorate of national education. Then, informed consent forms were obtained from the parents before the students participated in the study. In order to evaluate the life skills obtained through the sports, Life Skills Scale for Sport (LSSS) which is developed by Cronin and Allen (2017) and adapted to Turkish by Açak and Düz (2018) was used. The scale used consists of 30 items and 7 subscales such as team work, goal setting, time management, emotional skills, communication, social skills and leadership. Each item in the scale is scored on the 5-point Likert scale ranging from "I strongly disagree (1)" to "I totally agree (5)". The scale can be applied from secondary school to university students, takes 5-10 minutes to complete and there are no reverse scored questions in the scale.

\subsection{Data Analysis}

The data obtained in the study were evaluated using the IBM statistics (SPSS version 25.0, Armonk, NY, USA) windows package program. The normality of the data was tested by Kolmogorov-Smirnov, skewness and kurtosis tests. In groups that did not show normal distribution, While Mann-Whitney U test was used for paired comparisons, Kruskal-Wallis H test was used for multiple comparisons. Moreover, post-hoc test was used to find the source of the difference in multiple comparisons. The results were evaluated in the $95 \%$ confidence interval and the level of significance was considered as $\mathrm{p}<.05$.

\section{Findings}

It is seen that mean scores of social and emotional skills subscale of LSSS of female students are significantly higher than that of male students Table 2.

There are significant differences in leadership and goal setting subscales of LSSS of the students who participated in the study Table 3. It was seen that the leadership and goal setting mean scores of the 18-year-old students doing sports were lower than those of 15, 16 and 17-years-old students.

It was seen that there were significant differences in the subscales of leadership, social skills, emotional skills and goal setting in Table 4. Mean scores of the Anatolian and science high school students were higher than those of business high school students in the leadership subscale, and Anatolian and business high school students were higher than those of sports high school students in the social skills subscale. However, mean scores of the Anatolian and business high school students were lower than those of sport high school students in the emotional 
skills subscale. Finally, mean scores of the Anatolian, sport and science high school students were lower than those of business high school students in the goal setting subscale.

Table-2. Relationships between the gender and LSSE subscales.

\begin{tabular}{|c|c|c|c|c|c|}
\hline Subscales & Gender & $\mathbf{N}$ & $\overline{\mathbf{x}} \pm \mathrm{SD}$ & $\mathbf{z}$ & $\mathbf{p}$ \\
\hline \multirow{2}{*}{ Time Management } & Male & 305 & $3.83 \pm .66$ & \multirow{2}{*}{-.298} & \multirow{2}{*}{.766} \\
\hline & Female & 195 & $3.82 \pm .66$ & & \\
\hline \multirow{2}{*}{ Communication } & Male & 305 & $3.80 \pm .71$ & \multirow{2}{*}{-1.609} & \multirow{2}{*}{.108} \\
\hline & Female & 195 & $3.89 \pm .76$ & & \\
\hline \multirow{2}{*}{ Leadership } & Male & 305 & $3.70 \pm .63$ & \multirow{2}{*}{-1.449} & \multirow{2}{*}{.147} \\
\hline & Female & 195 & $3.77 \pm .70$ & & \\
\hline \multirow{2}{*}{ Teamwork } & Male & 305 & $3.89 \pm .68$ & \multirow{2}{*}{-.255} & \multirow{2}{*}{.799} \\
\hline & Female & 195 & $3.88 \pm .73$ & & \\
\hline \multirow{2}{*}{ Social skills } & Male & 305 & $3.81 \pm .67$ & \multirow{2}{*}{-2.429} & \multirow{2}{*}{$.015^{*}$} \\
\hline & Female & 195 & $3.93 \pm .74$ & & \\
\hline \multirow{2}{*}{ Emotional Skills } & Male & 305 & $3.58 \pm .76$ & \multirow{2}{*}{-2.301} & \multirow{2}{*}{$.021 *$} \\
\hline & Female & 195 & $3.74 \pm .79$ & & \\
\hline \multirow{2}{*}{ Goal-Setting } & Male & 305 & $3.96 \pm .72$ & \multirow{2}{*}{-.149} & \multirow{2}{*}{.881} \\
\hline & Female & 195 & $3.95 \pm .81$ & & \\
\hline
\end{tabular}

Table-3. Relationships between the age and LSSE subscales.

\begin{tabular}{|c|c|c|c|c|c|c|}
\hline Subscales & Age & $\mathbf{N}$ & $\overline{\mathbf{x}} \pm \mathbf{S D}$ & $\chi^{2}$ & p & Post-Hoc \\
\hline \multirow{4}{*}{ Time Management } & 15 & 111 & $3.84 \pm .62$ & \multirow{4}{*}{.488} & \multirow{4}{*}{.922} & \\
\hline & 16 & 190 & $3.83 \pm .68$ & & & \\
\hline & 17 & 129 & $3.82 \pm .66$ & & & \\
\hline & 18 & 70 & $3.81 \pm .69$ & & & \\
\hline \multirow{4}{*}{ Communication } & 15 & 111 & $3.81 \pm .66$ & \multirow{4}{*}{1.465} & \multirow{4}{*}{.690} & \\
\hline & 16 & 190 & $3.80 \pm .81$ & & & \\
\hline & 17 & 129 & $3.91 \pm .68$ & & & \\
\hline & 18 & 70 & $3.81 \pm .73$ & & & \\
\hline \multirow{4}{*}{ Leadership } & $15^{\mathrm{a}}$ & 111 & $3.80 \pm .68$ & \multirow{4}{*}{8.807} & \multirow{4}{*}{$.032 *$} & \multirow{4}{*}{$\mathrm{d}<\mathrm{a}, \mathrm{b}, \mathrm{c}$} \\
\hline & $16^{\mathrm{b}}$ & 190 & $3.73 \pm .69$ & & & \\
\hline & $17^{\mathrm{c}}$ & 129 & $3.77 \pm .57$ & & & \\
\hline & $18^{\mathrm{d}}$ & 70 & $3.50 \pm .67$ & & & \\
\hline \multirow{4}{*}{ Teamwork } & 15 & 111 & $3.98 \pm .71$ & \multirow{4}{*}{7.643} & \multirow{4}{*}{.054} & \\
\hline & 16 & 190 & $3.88 \pm .70$ & & & \\
\hline & 17 & 129 & $3.92 \pm .62$ & & & \\
\hline & 18 & 70 & $3.68 \pm .78$ & & & \\
\hline \multirow{4}{*}{ Social skills } & 15 & 111 & $3.86 \pm .71$ & \multirow{4}{*}{2.500} & \multirow{4}{*}{.475} & \\
\hline & 16 & 190 & $3.84 \pm .72$ & & & \\
\hline & 17 & 129 & $3.93 \pm .67$ & & & \\
\hline & 18 & 70 & $3.78 \pm .71$ & & & \\
\hline \multirow{4}{*}{ Emotional skills } & 15 & 111 & $3.73 \pm .72$ & \multirow{4}{*}{3.174} & \multirow{4}{*}{.366} & \\
\hline & 16 & 190 & $3.64 \pm .82$ & & & \\
\hline & 17 & 129 & $3.62 \pm .74$ & & & \\
\hline & 18 & 70 & $3.53 \pm .80$ & & & \\
\hline \multirow{4}{*}{ Goal-setting } & $15^{\mathrm{a}}$ & 111 & $4.10 \pm .69$ & \multirow{4}{*}{19.240} & \multirow{4}{*}{$.000^{*}$} & \multirow{4}{*}{$\mathrm{d}<\mathrm{a} . \mathrm{b}, \mathrm{c}$} \\
\hline & $16^{\mathrm{b}}$ & 190 & $4.03 \pm .78$ & & & \\
\hline & $17^{\mathrm{c}}$ & 129 & $3.91 \pm .73$ & & & \\
\hline & $18^{\mathrm{d}}$ & 70 & $3.63 \pm .79$ & & & \\
\hline
\end{tabular}

Table-4. Relationships between the school type and LSSE subscales.

\begin{tabular}{|c|c|c|c|c|c|c|}
\hline Subscales & School Type & $\mathbf{N}$ & $\overline{\mathbf{x}} \pm \mathbf{S D}$ & $\chi^{2}$ & $\mathbf{P}$ & Post-Hoc \\
\hline \multirow{4}{*}{ Time Management } & 1.Anatolian High School & 134 & $3.87 \pm .62$ & \multirow{4}{*}{1.489} & \multirow{4}{*}{.685} & \\
\hline & 2.Business High School & 131 & $3.77 \pm .71$ & & & \\
\hline & 3.Sport High School & 171 & $3.81 \pm .71$ & & & \\
\hline & 4.Science High School & 64 & $3.89 \pm .47$ & & & \\
\hline \multirow{4}{*}{ Communication } & 1.Anatolian High School & 134 & $3.85 \pm .71$ & \multirow{4}{*}{5.985} & \multirow{4}{*}{.112} & \\
\hline & 2.Business High School & 131 & $3.78 \pm .72$ & & & \\
\hline & 3.Sport High School & 171 & $3.79 \pm .77$ & & & \\
\hline & 4.Science High School & 64 & $4.01 \pm .69$ & & & \\
\hline \multirow{4}{*}{ Leadership } & 1.Anatolian High School & 134 & $3.80 \pm .65$ & \multirow{4}{*}{14.358} & \multirow{4}{*}{$.002^{*}$} & \multirow{4}{*}{$2<1,4$} \\
\hline & 2.Business High School & 131 & $3.59 \pm .65$ & & & \\
\hline & 3.Sport High School & 171 & $3.71 \pm .72$ & & & \\
\hline & 4.Science High School & 64 & $3.88 \pm .44$ & & & \\
\hline \multirow{4}{*}{ Teamwork } & 1.Anatolian High School & 134 & $3.93 \pm .63$ & \multirow{4}{*}{3.828} & \multirow{4}{*}{.281} & \\
\hline & 2.Business High School & 131 & $3.79 \pm .76$ & & & \\
\hline & 3.Sport High School & 171 & $3.87 \pm .75$ & & & \\
\hline & 4.Science High School & 64 & $4.04 \pm .52$ & & & \\
\hline Social skills & 1.Anatolian High School & 134 & $3.89 \pm .72$ & 11.534 & $.009^{*}$ & $3<1,2$ \\
\hline
\end{tabular}




\begin{tabular}{|c|c|c|c|c|c|c|}
\hline & 2.Business High School & 131 & $3.89 \pm .70$ & & & \\
\hline & 3.Sport High School & 171 & $3.74 \pm .71$ & & & \\
\hline & 4.Science High School & 64 & $4.05 \pm .61$ & & & \\
\hline \multirow{4}{*}{ Emotional skills } & 1.Anatolian High School & 134 & $3.57 \pm .76$ & \multirow{4}{*}{8.614} & \multirow{4}{*}{$.035^{*}$} & \multirow{4}{*}{$4>1,2$} \\
\hline & 2.Business High School & 131 & $3.57 \pm .68$ & & & \\
\hline & 3.Sport High School & 171 & $3.69 \pm .84$ & & & \\
\hline & 4.Science High School & 64 & $3.80 \pm .78$ & & & \\
\hline \multirow{4}{*}{ Goal-setting } & 1.Anatolian High School & 134 & $4.03 \pm .70$ & \multirow{4}{*}{14.681} & \multirow{4}{*}{$.002 *$} & \multirow{4}{*}{$2<1,3,4$} \\
\hline & 2.Business High School & 131 & $3.74 \pm .79$ & & & \\
\hline & 3.Sport High School & 171 & $4.04 \pm .77$ & & & \\
\hline & 4.Science High School & 64 & $4.04 \pm .72$ & & & \\
\hline
\end{tabular}

Table-5. Relationships between the club license and LSSE subscales.

\begin{tabular}{|c|c|c|c|c|c|}
\hline Subscales & Club License & $\mathbf{N}$ & $\overline{\mathbf{x}} \pm \mathbf{S D}$ & $\mathbf{z}$ & $\mathbf{p}$ \\
\hline \multirow{2}{*}{ Time Management } & Yes & 233 & $3.94 \pm .63$ & \multirow{2}{*}{3.811} & \multirow{2}{*}{$.000^{*}$} \\
\hline & No & 267 & $3.73 \pm .67$ & & \\
\hline \multirow{2}{*}{ Communication } & Yes & 233 & $3.89 \pm .74$ & \multirow{2}{*}{1.679} & \multirow{2}{*}{.093} \\
\hline & No & 267 & $3.78 \pm .72$ & & \\
\hline \multirow{2}{*}{ Leadership } & Yes & 233 & $3.80 \pm .64$ & \multirow{2}{*}{2.451} & \multirow{2}{*}{$.014^{*}$} \\
\hline & No & 267 & $3.66 \pm .67$ & & \\
\hline \multirow{2}{*}{ Teamwork } & Yes & 233 & $3.96 \pm .71$ & \multirow{2}{*}{2.595} & \multirow{2}{*}{$.009^{*}$} \\
\hline & No & 267 & $3.82 \pm .68$ & & \\
\hline \multirow{2}{*}{ Social skills } & Yes & 233 & $3.89 \pm .68$ & \multirow{2}{*}{1.107} & \multirow{2}{*}{.268} \\
\hline & No & 267 & $3.83 \pm .72$ & & \\
\hline \multirow{2}{*}{ Emotional Skills } & Yes & 233 & $3.67 \pm .76$ & \multirow{2}{*}{1.071} & \multirow{2}{*}{.284} \\
\hline & $\mathrm{No}$ & 267 & $3.61 \pm .79$ & & \\
\hline \multirow{2}{*}{ Goal-Setting } & Yes & 233 & $4.05 \pm .76$ & \multirow{2}{*}{.284} & \multirow{2}{*}{$.004^{*}$} \\
\hline & $\mathrm{No}$ & 267 & $3.88 \pm .75$ & & \\
\hline
\end{tabular}

It was seen that mean scores of students who have club license were significantly higher than those of students who have not in time management, leadership, teamwork and goal setting subscales Table 5 .

\begin{tabular}{|c|c|c|c|c|c|c|}
\hline Subscale & Sport year & $\mathbf{N}$ & $\overline{\mathbf{x}} \pm \mathbf{S D}$ & $\chi^{2}$ & $\mathbf{p}$ & Post-hoc \\
\hline \multirow{4}{*}{$\begin{array}{l}\text { Time } \\
\text { Management }\end{array}$} & $O-2^{\text {a }}$ & 160 & $3.74 \pm .67$ & \multirow{4}{*}{10.426} & \multirow{4}{*}{$.015^{*}$} & \multirow{4}{*}{$d>a, b$} \\
\hline & $3-5^{\mathrm{b}}$ & 185 & $3.82 \pm .69$ & & & \\
\hline & $6-7^{c}$ & 81 & $3.83 \pm .61$ & & & \\
\hline & $\geq 8^{\mathrm{d}}$ & 74 & $4.01 \pm .61$ & & & \\
\hline \multirow{4}{*}{ Communication } & $\mathrm{O}-2$ & 160 & $3.82 \pm .74$ & \multirow{4}{*}{2.206} & \multirow{4}{*}{.531} & \\
\hline & $3-5$ & 185 & $3.80 \pm .72$ & & & \\
\hline & $6-7$ & 81 & $3.83 \pm .76$ & & & \\
\hline & $\geq 8$ & 74 & $3.95 \pm .71$ & & & \\
\hline \multirow{4}{*}{ Leadership } & $0-2$ & 160 & $3.67 \pm .69$ & \multirow{4}{*}{6.941} & \multirow{4}{*}{.074} & \\
\hline & $3-5$ & 185 & $3.75 \pm .66$ & & & \\
\hline & $6-7$ & 81 & $3.65 \pm .69$ & & & \\
\hline & $\geq 8$ & 74 & $3.87 \pm .54$ & & & \\
\hline \multirow{4}{*}{ Teamwork } & $0-2$ & 160 & $3.81 \pm .70$ & \multirow{4}{*}{3.712} & \multirow{4}{*}{.294} & \\
\hline & $3-5$ & 185 & $3.92 \pm .63$ & & & \\
\hline & $6-7$ & 81 & $3.88 \pm .80$ & & & \\
\hline & $\geq 8$ & 74 & $3.96 \pm .72$ & & & \\
\hline \multirow{4}{*}{ Social skills } & $0-2$ & 160 & $3.84 \pm .72$ & \multirow{4}{*}{2.622} & \multirow{4}{*}{.454} & \\
\hline & $3-5$ & 185 & $3.88 \pm .66$ & & & \\
\hline & $6-7$ & 81 & $3.79 \pm .69$ & & & \\
\hline & $\geq 8$ & 74 & $3.92 \pm .76$ & & & \\
\hline \multirow{4}{*}{ Emotional skills } & $0-2$ & 160 & $3.58 \pm .75$ & \multirow{4}{*}{4.235} & \multirow{4}{*}{.237} & \\
\hline & $3-5$ & 185 & $3.71 \pm .74$ & & & \\
\hline & $6-7$ & 81 & $3.53 \pm .84$ & & & \\
\hline & $\geq 8$ & 74 & $3.70 \pm .82$ & & & \\
\hline \multirow{4}{*}{ Goal-setting } & $\mathrm{O}-2^{\mathrm{a}}$ & 160 & $3.84 \pm .77$ & \multirow{4}{*}{9.141} & \multirow{4}{*}{$.027 *$} & \multirow{4}{*}{$d>a$} \\
\hline & $3-5^{\mathrm{b}}$ & 185 & $4.01 \pm .71$ & & & \\
\hline & $6-7^{\mathrm{c}}$ & 81 & $3.94 \pm .85$ & & & \\
\hline & $\geq 8^{d}$ & 74 & $4.12 \pm .73$ & & & \\
\hline
\end{tabular}

There were significant mean differences in time management and goal setting subscales in terms of sport year according to Table 6 . In the time management subscale, mean scores of the students who were doing sports for between 0-2 and 3-5 years were significantly lower than those of students who were doing sports for 8 years and more. Moreover, in the goal setting subscale mean score of the students who were doing sports for 8 years and more were significantly higher than those of students who were doing sports for 0-2 years. 
Table-7. Relationships between number of weekly training and LSSE subscales.

\begin{tabular}{|c|c|c|c|c|c|c|}
\hline Subscales & Number of Weekly Training & $\mathbf{N}$ & $\overline{\mathbf{x}} \pm \mathbf{S D}$ & $\chi^{2}$ & $\mathbf{p}$ & Post-Hoc \\
\hline \multirow{4}{*}{ Time Management } & $2^{\mathrm{a}}$ & 73 & $3.67 \pm .63$ & \multirow{4}{*}{18.205} & \multirow{4}{*}{$.000^{*}$} & \multirow{4}{*}{$\mathrm{d}>\mathrm{a}, \mathrm{b}$} \\
\hline & $3^{\mathrm{b}}$ & 209 & $3.75 \pm .67$ & & & \\
\hline & $4^{c}$ & 108 & $3.90 \pm .65$ & & & \\
\hline & $\geq 5^{\mathrm{d}}$ & 110 & $4.01 \pm .62$ & & & \\
\hline \multirow{4}{*}{ Communication } & 2 & 73 & $3.72 \pm .82$ & \multirow{4}{*}{2.796} & \multirow{4}{*}{.424} & \\
\hline & 3 & 209 & $3.81 \pm .70$ & & & \\
\hline & 4 & 108 & $3.88 \pm .72$ & & & \\
\hline & $\geq 5$ & 110 & $3.90 \pm .74$ & & & \\
\hline \multirow{4}{*}{ Leadership } & $2^{\mathrm{a}}$ & 73 & $3.51 \pm .74$ & \multirow{4}{*}{7.899} & \multirow{4}{*}{$.048 *$} & \multirow{4}{*}{$\mathrm{a}<\mathrm{c}, \mathrm{d}$} \\
\hline & $3^{\mathrm{b}}$ & 209 & $3.71 \pm .68$ & & & \\
\hline & $4^{\mathrm{c}}$ & 108 & $3.80 \pm .61$ & & & \\
\hline & $\geq 5^{\mathrm{d}}$ & 110 & $3.81 \pm .58$ & & & \\
\hline \multirow{4}{*}{ Teamwork } & 2 & 73 & $3.75 \pm .64$ & \multirow{4}{*}{6.760} & \multirow{4}{*}{.080} & \\
\hline & 3 & 209 & $3.87 \pm .71$ & & & \\
\hline & 4 & 108 & $3.97 \pm .70$ & & & \\
\hline & $\geq 5$ & 110 & $3.92 \pm .70$ & & & \\
\hline \multirow{4}{*}{ Social skills } & 2 & 73 & $3.77 \pm .80$ & \multirow{4}{*}{2.721} & \multirow{4}{*}{.437} & \\
\hline & 3 & 209 & $3.85 \pm .66$ & & & \\
\hline & 4 & 108 & $3.87 \pm .71$ & & & \\
\hline & $\geq 5$ & 110 & $3.92 \pm .71$ & & & \\
\hline \multirow{4}{*}{ Emotional skills } & $2^{\mathrm{a}}$ & 73 & $3.39 \pm .80$ & \multirow{4}{*}{10.522} & \multirow{4}{*}{$.015^{*}$} & \multirow{4}{*}{$\mathrm{a}<\mathrm{b}, \mathrm{c}, \mathrm{d}$} \\
\hline & $3^{\mathrm{b}}$ & 209 & $3.63 \pm .76$ & & & \\
\hline & $4^{\mathrm{c}}$ & 108 & $3.76 \pm .74$ & & & \\
\hline & $\geq 5^{\mathrm{d}}$ & 110 & $3.70 \pm .78$ & & & \\
\hline \multirow{4}{*}{ Goal-setting } & $2^{\mathrm{a}}$ & 73 & $3.63 \pm .84$ & \multirow{4}{*}{18.765} & \multirow{4}{*}{$.000^{*}$} & \multirow{4}{*}{$\mathrm{a}<\mathrm{b}, \mathrm{c}, \mathrm{d}$} \\
\hline & $3^{\mathrm{b}}$ & 209 & $3.94 \pm .72$ & & & \\
\hline & $4^{c}$ & 108 & $4.09 \pm .70$ & & & \\
\hline & $\geq 5^{\mathrm{d}}$ & 110 & $4.07 \pm .77$ & & & \\
\hline
\end{tabular}

It is found that there were significant mean differences in time management, leadership, emotional skills and goal setting subscales in terms of number of weekly training in Table 7 . In the time management subscale, mean score of students who train 5 times or more in a week were higher than those of the students who train 2 and 3 times a week. In the leadership subscale, mean score of students who train 5 times or more in a week were higher than those of the students who train 2 and 3 times a week. But, mean score of students who train 3,4 and 5 times or more in a week were higher than those of the students who train 2 times a week in emotional and goal setting subscales.

\section{Discussion and Results}

This study was conducted to examine the effect of sports on the life skills of high school students in terms of various variables. The results of the study exhibited a significant relationship between the age and subscales of leadership and goal setting at LSSS. It was observed that as the age of students increased, the development of sports life skills decreased. These results suggest that functional age as well as chronological age may be effective in goal setting and leadership power in sports. According to gender variable, the emotional and social skills mean score of females who were engaged in sports were higher than those of males, and it demonstrated that sport positively affected their life skills. In the literature, in many studies which are supporting the findings of this study (Avşar and Kuter, 2007; Kabakçı and Fidan, 2008; Seven, 2008). They were found that females have more social and communication skills than those of males.

According to the school variable, it has been determined that goal setting and leadership mean scores of science and Anatolian high school students were higher than others. Cansoy (2015) which is supporting the findings of this study was conducted on 1123 students in secondary school education showed that students with high academic achievement and who read more books were found to have higher mean scores of leaderships.

As the sport year considered, students who were doing sport for a long-term, i.e. eight and over, used their time more efficiently and developed well goal settings than others. Moreover, there was a significant relationship between club license and time management, goal setting, group work and leadership subscale of LSSS. It is concluded that being licensed in a team and having regular sports activities positively affect many life skills such as work together, ability to reach the goal, time management and leadership characteristics (Rothschild-Checroune et al., 2012).

According to the number of weekly training variable, the higher the number of weekly training, the better control of time and emotions of students, and goal setting and leadership characteristics were also positively affected. Results of Reynolds et al. (1990) supports our study. They stated that regular physical activity affected quality of life and other psychological variables positively, and showed that exercise had a positive effect on expectation of social competence, stress and social factors.

Ryan and Dzewaltowski (2002) found that self-confidence of 6th and 7th grade students increased with physical activity, they overcame obstacles with physical activity, encouraging other friends to be active, discovering and creating environment, and being more enterprising.

In this study, there was no significant relationship found between life skills and sports branches of the students. Sport may have an effect on the life skills, but whether participating individual or team sport do not make difference. Doing sports with an amateur spirit causes students to increase their life skills. Because participating in sports activities on behalf of a club causes students to be disciplined and more motivated. Moreover, as the number 
of weekly training and sport age increased, development of life skills increased. These results demonstrated the importance of directing and encouraging young people to do sport since sport has positive contributions not only to physical features but also to personal characteristics that shape our daily lives.

In contrast to the expectations, sport experience, level of skill and chronological age can be taken into consideration to provide more detailed information while examining the relationship between the age and goal setting and leadership perceptions. If the level of goal setting and leadership characteristics are determined, defined and evaluated comprehensively, continuity can be ensured in developing and maintaining these characteristics (Kress, 2006).

As a conclusion, it is possible to meet the needs of young people in terms of both mentally and physically through sports in school age. The development of life skills in childhood and youth makes the subject even more important due to preparation for adulthood. Especially, for the young individuals, sports improve a lot of life skills such as team work, goal setting, taking initiative, respect for others, time management, leadership, problem solving, decision-making, cognitive, emotional, communicational and social skills.

\section{References}

Açak, M. and S. Düz, 2018. Adaptation of the effect of sport on life skills scale to turkish culture. Journal of İnönü University Educational Sciences Institute, 5(9): 74-86.Available at: https://doi.org/10.29129/inujgse.360711.

Avşar, Z. and F. Kuter, 2007. Determination of social skills level in students of uludağ university physical education and sports department. Journal of Theory and Practice in Education, 3(2): 197-206.

Aydemir, I., 2014. Evaluation of school sports activities carried out by the general directorate of sports, bolu sample. Abant Izzet Baysal University, Institue of Social Science, Department of Physıcal Education and Sports, Master Thesis, Bolu.

Camiré, M. and K. Kendellen, 2016. Coaching for positive youth development in high school sport. In n.L., holt (ed.). Positive youth development through sport. Routledge, London, UK: pp: 126-136.

Cansoy, R., 2015. Study of youth leadership qualities of high school students in turkey. Eskisehir Osmangazi University, Institute of Education Sciences, Department of Education Sciences, Doctorate Thesis, Eskisehir.

Catalano, R.F., M.L. Berglund, J.A. Ryan, H.S. Lonczak and J.D. Hawkins, 2004. Positive youth development in the united states: Research findings on evaluations of positive youth development programs. The Annals of the American Academy of Political and Social Science, 591(1): 98-124.

Caterino, M.C. and E.D. Polak, 1999. Effects of two types of activity on the performance of second-, third-, and fourth-grade students on a test of concentration. Perceptual and Motor Skills, 89(1): 245-248.Available at: https://doi.org/10.2466/pms.1999.89.1.245.

Cetin, F., B.A. Alpa and K. Albayrak, D., 2003. Social skills in children from research to practice. 3rd Edn., Istanbul: Epsilon.

Cronin, L.D. and J. Allen, 2017. Development and initial validation of the life skills scale for sport. Psychology of Sport and Exercise, 28: 105-1 19.Available at: https://doi.org/10.1016/j.psychsport.2016.11.001.

Cronin., L.D. and J.B. Allen, 2015. Developmental experiences and well-being in sport: The importance of the coaching climate. The Sport Psychologist, 29(1): 62-71.Available at: https://doi.org/10.1123/tsp.2014-0045.

Danish, S., T. Forneris, K. Hodge and I. Heke, 2004. Enhancing youth development through sport. World Leisure Journal, 46(3): 38-49.

Eime, R.M., J.A. Young, J.T. Harvey, M.J. Charity and W.R. Payne, 2013. A systematic review of the psychological and social benefits of participation in sport for children and adolescents: Informing development of a conceptual model of health through sport. International Journal of Behavioral Nutrition and Physical Activity, 10(1): 1-21.Available at: https://doi.org/10.1186/1479-5868$10-98$.

Gazda, G.M. and D. Brooks Jr, 1985. Social/life-skills training. Journal of Group Psychotherapy, Psychodrama and Sociometry, $38(1)$ : 1-65.

Ghildiyal, R., 2015. Role of sports in the development of an individual and role of psychology in sports. Mens Sana Monographs, 13(1): 165170.Available at: https://doi.org/10.4103/0973-1229.153335.

Goldsmith, E.B., 2000. Resource management for individuals and families. 2nd Edn., United States: Wadsworth Thomson Learning.

Gould, D. and S. Carson, 2008. Life skills development through sport: Current status and future directions. International Review of Sport and Exercise Psychology, 1(1): 58-78.

Gould, D., K. Collins, L. Lauer and Y. Chung, 2007. Coaching life skills through football: A study of award winning high school coaches. Journal of Applied Sport Psychology, 19(1): 16-37.Available at: https://doi.org/10.1080/10413200601113786.

Hejazi, E., N. Babakhani and S.N. Ahmadi, 2017. Investigating the impact of interpersonal communication skills on social development among female students. Tendenzen, 25(3): 1098-1111.

Hodge, K. and S. Danish, 1999. Promoting life skills for adolescent males through sport. In horne, a.M. And m.S. Kiselica. Handbook of counseling boys and adolescent males: A practitioner's guide (eds.). Sage, Newbury Park, CA: pp: 55-71.

Holt, N.L., K.C. Neely, L.G. Slater, M. Camiré, J. Côté, J. Fraser-Thomas, D. MacDonald, L. Strachan and K.A. Tamminen, 2017. A grounded theory of positive youth development through sport based on results from a qualitative meta-study. International Review of Sport and Exercise Psychology, 10(1): 1-49.Available at: https://doi.org/10.1080/1750984x.2016.1 180704.

Inal, A., 2003. Physical education and sports science. Ankara: Nobel.

Johnston, J., C. Harwood and A.M. Minniti, 2013. Positive youth development in swimming: Clarification and consensus of key psychosocial assets. Journal of Applied Sport Psychology, 25(4): 392-411.

Jones, M.I. and D. Lavallee, 2009. Exploring perceived life skills development and participation in sport. Qualitative Research in Sport and Exercise, 1(1): 36-50.

Kabakçı, Ö.F. and K. Fidan, 2008. Investigation of social-emotional learning skills of 6-8th grade students according to some variables. Education and Science, 33(148): 77-86.

Kohl, H.W. and H.D. Cook, 2013. Educating the student body: Taking physical activity and physical education to school. Committee on physical activity and physical education in the school environment; food and nutrition board; institute of medicine. Washington (DC): National Academies Press.

Kolburan, G. and U. Tosun, 2011. A developmental model proposal that reinforces the values acquired in the first stage through life skills education among primary school second grade students. pp: 246-247.

Korkut, F., 2004. School based preventive guidance and psychological counseling. Ankara: Anı Publishing.

Kress, C.A., 2006. Youth leadership and youth development: Connections and questions. New Directions for Youth Development, 2006(109): 45-56.Available at: https://doi.org/10.1002/yd.154.

Kumar, R., 2017. Impact of physical education and sports in promoting social values among youth. The International Journal of Indian Psychology, 4(2): 84-87.

Matson, J.L., M.L. Matson and T.T. Rivet, 2007. Social-skills treatments for children with autism spectrum disorders: An overview. Behavior Modification, 31(5): 682-707.

Nagaraju, M.T.V., 2016. Strategies to promote life-skills among adolescents. European Journal of Education Studies, 2(3): $112-119$.

Reynolds, K.D., J.D. Killen, S.W. Bryson, D.J. Maron, J.B. Taylor, N. Maccoloy and J.W. Farguhar, 1990. Psychosocial predictors of physical activity in adolescents. Previous Medicine, 19(5): 541-551.

Rothschild-Checroune, E., F. Gravelle, D. Dawson and G. Karlis, 2012. Balancing academic and athletic time management: A qualitative exploration of first year student athletes' university football experiences. Society and Leisure, 35(2): 243-261.Available at: https://doi.org/10.1080/07053436.2012.10707843.

Ryan, G.J. and D.A. Dzewaltowski, 2002. Comparing the relationships between different types of self-efficacy and physical activity in youth. Health Education \& Behavior, 29(4): 491-504.Available at: https://doi.org/10.1177/109019810202900408.

Seven, S., 2008. The study of seven-eight year-old children's social skills. Firat University Journal of Social Sciences, 18(2): 151-174. 
Sümbüloğlu, K. and V. Sümbüloğlu, 2009. Biostatistics. Ankara: Hatipoğlu Publishing.

Whitley, M.A., W.V. Massey and N.M. Leonetti, 2016. 'Greatness (un) channelled': The role of sport in the life of an elite athlete who overcame multiple developmental risk factors. Qualitative Research in Sport, Exercise and Health, 8(2): 194-212.Available at: https://doi.org/10.1080/2159676x.2015.1121913.

WHO, 1997. Life skills education for children and adolescents in schools: Introduction and guidelines to facilitate the development and implementation of life skills programmes. Geneva, Switzerland: WHO Programme on Mental Health. 